\title{
Haptoglobin Phenotypes Among Egyptians*
}

\author{
NEMAT HASHEM, K. KAMEL, and E. I. HAMMOUD \\ From the Medical Genetics Unit, Ain-Shams University, Cairo, U.A.R.
}

Serum haptoglobins have been found to be useful genetic markers. The distribution of the different haptoglobin genes was found to vary in different parts of the world (Giblett, 196I). Thus Orientals and Eskimos were found to have a high incidence of the gene $\mathrm{Hp}^{2}$ and Negroes a high incidence of $\mathrm{Hp}^{1}$. Caucasians in continental Europe, Australia, and the United States have revealed an intermediate distribution of these 2 genes as have also the Australian aborigines. In studying American Indian populations both Blumberg, Allison, and Garry (1959) and Sutton, Matson, Robinson, and Koucky (1960) pointed out an increasing gene frequency of $\mathrm{Hp}^{1}$ as one goes south.

The present study aims primarily at describing the distribution of haptoglobin phenotypes among Egyptians, which has not been done before. Some observations on haptoglobin patterns in certain hereditary disease states are also included.

\section{Methods}

Haptoglohin typing was done by Smithies' method (1959) using starch-gel electrophoresis. Sera were studied from 219 normal adults (blood donors), from 66 patients with hereditary CNS diseases, and from 53 of their normal relatives. Statistical analysis was done using the chi-square test.

The results are shown in Tables I and II.

\section{Discussion}

The relative distribution of the three common haptoglobin phenotypes (HpI-I, $\mathrm{Hp}_{2-\mathrm{I}}+\mathrm{Hp}_{2}-\mathrm{I}$ modified, Hp2-2) among normal Egyptians is $4.1 \%, 34.24 \%$, and $61.64 \%$, respectively; (gene proportion being 0.2123 for $\mathrm{Hp}^{1}$ and 0.7877 for $\mathrm{Hp}^{2}$ ). This distribution simulates prevalent patterns among Oriental races. Thus Sutton et al. (1960), in a study of haptoglobin phenotypes among 200 Japanese blood donors, found $4 \%$,

Received June 2, 1966.

* This study has been assisted by Grant No. 4 X-2507 of the National Institutes of Health, Bethesda, Maryland, U.S.A.
$35 \%$, and $58 \%$, respectively. This pattern contrasts with that prevalent among several other African populations where the $\mathrm{Hp}^{1}$ gene is the commoner, and among Europeans where $\mathrm{Hp}^{1}$ and $\mathrm{Hp}^{2}$ genes are approximately equal (Giblett, I96I).

It is of interest that no significant difference is found between the haptoglobin phenotypes in upper and lower Egypt. Since Egypt has been frequently invaded by foreigners, e.g. Asiatics (Persians, Arabs, and Turks) as well as Europeans (Greek, Roman, French, and British), Egyptians have had several chances for gene admixture. Any such admixture would be generally greater in the population of Lower Egypt (from Cairo downstream, i.e. the Nile Delta), being the part of the country facing the invaders from North or across the Sinai Peninsula. Upper Egypt (upstream from Cairo) is surrounded on both sides by vast areas of desert and mountains. The Turk and Arab have apparently contributed most to any genetic exchange with Egyptians on a common religion basis, Islam. A detailed survey of hapto-

\section{TABLE I}

HAPTOGLOBIN PHENOTYPES AMONG THREE STUDY GROUPS (NORMAL SUBJECTS, SELECTED PATIENTS HAVING HEREDITARY DISEASES, AND THEIR NORMAL RELATIVES)

\begin{tabular}{|c|c|c|c|c|c|}
\hline \multirow{2}{*}{ Study Group } & \multicolumn{4}{|c|}{ Haptoglobin Phenotype } & \multirow{2}{*}{ Total } \\
\hline & $\mathbf{I}-\mathbf{I}$ & 2-I & $2-2$ & $0-0$ & \\
\hline I. Normals $\left\{\begin{array}{l}\text { Upper Egypt } \\
\text { Lower Egypt }\end{array}\right.$ & $\begin{array}{l}5 \\
4\end{array}$ & $\begin{array}{l}38 \\
37\end{array}$ & $\begin{array}{l}69 \\
66\end{array}$ & - & $\begin{array}{l}\text { I } 12 \\
107\end{array}$ \\
\hline Total & $(0.95)$ & $\begin{array}{c}75 \\
(0.34)\end{array}$ & $\begin{array}{l}135 \\
(0.6 I) \\
\end{array}$ & - & 219 \\
\hline $\begin{array}{l}\text { II. Normal relatives of disea- } \\
\text { sed patients in group III } \\
\text { - sibs and parents) }\end{array}$ & $(0.08)$ & $\begin{array}{l}2 I^{*} \\
(0 \cdot 4)\end{array}$ & $\begin{array}{l}25 \\
(0 \cdot 48)\end{array}$ & $\left(\begin{array}{c}2 \\
(0.04)\end{array}\right.$ & 53 \\
\hline $\begin{array}{l}\text { III. Patients with CNS heredo- } \\
\text { familial diseases }\end{array}$ & $\left(\begin{array}{c}9 \\
0.13)\end{array}\right.$ & $\begin{array}{l}29 t \\
(0.46)\end{array}$ & $\begin{array}{l}28 \\
(041)\end{array}$ & - & 66 \\
\hline
\end{tabular}

( ) Figures between brackets represent proportions of haptoglobin genotypes.

* Including $\mathrm{I}$ case $\mathrm{Hp}^{2-1}$ Johnson type.

† Including I case $\mathrm{Hp}^{2-1}$ modified. 
TABLE II

TESTING HYPOTHESIS OF HARDY-WEINBERG EQUILIBRIUM LAW OF HAPTOGLOBIN GENES IN NORMAL GROUP AND IN CNS HEREDO-FAMILIAL DISEASE GROUP

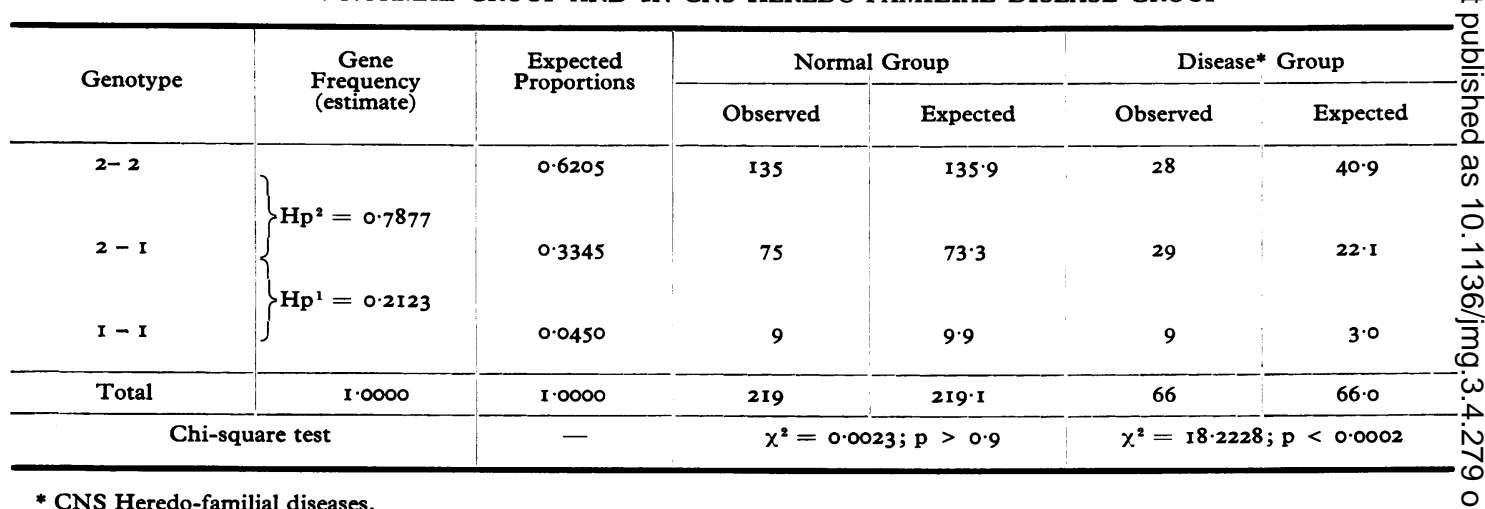

globin phenotypes among pure Turk and Arab populations would aid in clarifying the evolution of the present haptoglobin phenotypes as well as other genetic markers among Egyptians.

The data in Table I show a somewhat higher incidence of $\mathrm{Hp}^{1-1}$ in the hereditary CNS disease group than in the normal subjects, the unaffected relatives showing an intermediate incidence. Although the difference between the relatives and the normal subjects is not statistically significant $(\mathrm{p}>0.2)$ the higher incidence in the hereditary disease group is statistically significant $(0.025>\mathrm{p}>$ $0.05)$.

The expected proportions of the 3 haptoglobin genotypes in the normal group are in accordance with the Hardy-Weinberg law tested by the chisquare method where the gene frequencies are $\mathrm{Hp}^{1}=0.2123$ and $\mathrm{Hp}^{2}=0.7877$. The value of $\chi^{2}\left(\chi^{2}=0.0023, p>0.9\right)$ shows a very insignificant deviation between the observed and expected numbers. In the CNS heredo-familial group however, the frequencies are different $\left(\chi^{2}=18.2228\right.$, $\mathrm{p}<0.0002$ ), and the observed proportions deviate conspicuously from the expected (Table II).

The implication of the significant relative increase in incidence of $\mathrm{Hp}^{1-1}$ phenotype among patients with hereditary CNS disease compared to normal subjects cannot be explained by available data, yet the evident increase in consanguineous marriage in several generations of families of those patients may be a perpetuating factor for an originally accidental association between the $\mathrm{Hp}^{1}$ gene and the gene(s) responsible for the CNS disease. However, any selective influence of those genes on different haptoglobins remains speculative.

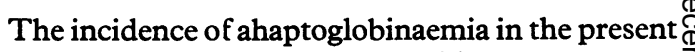
study $(0.73 \%$ out of total normals) contrasts very 3 much with its incidence among various populations $\underset{-}{\mathbb{1}}$ of the African continent where variable percentages $\vec{A}$ amounting to $4 \mathrm{r} \%$ in West Africa were reported $\mathscr{\odot}$ (Allison, Blumberg, and Rees, 1958; Sutton, Neel, Livingston, Binson, Kunstadter, and Trombley, 1959; Harris, Robson, and Siniscalco, 1958; Giblett and Steinberg, 1960).

\section{Summary}

A study of haptoglobin phenotypes among $\overrightarrow{\vec{F}}$ Egyptians indicates a high prevalence of the gene $\exists$ $\mathrm{Hp}^{2}$. The $\mathrm{Hp}^{1}$ gene was found in a somewhat higher incidence in a group of patients with hereditary diseases of the central nervous system.

\section{REFERENCES}

Allison, A. C., Blumberg, B. S., and ap Rees, Mrs. (1958). Hapto- 3 globin types in British, Spanish Basque and Nigerian African populations. Nature (Lond.), 181, 824 .

Blumberg, B. S., Allison, A. C., and Garry, B. (1959). The haptoglobins and haemoglobins of Alaskan Eskimos and Indians. Ann. hum. Genet., 23, 349.

Giblett, E. (196I). In Proceedings of the Conference on Genetic Polymorphisms and Geographic Variations in Disease, ed. B. S.음 Blumberg, pp. 14I-142. Grune and Stratton, New York.

Giblett, E. R., and Steinberg, A. G. (1960). The inheritance of $N$ serum haptoglobin types in American Negroes: evidence for a $\mathrm{G}$ third allele $H_{p}^{2 m}$. Amer. F. hum. Genet., 12, 160.

Harris, H., Robson, E. B., and Siniscalco, M. (1958). B-globulin variants in man. Nature (Lond.), 182, 452.

Smithies, O. (1959). Zone electrophoresis in starch gels and its $\omega$ application to studies of serum proteins. Advanc. Protein Chem.

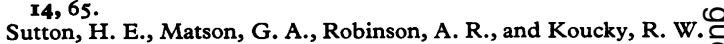
(1960). Distribution of haptoglobin, transferrin, and hemoglobin $\mathbb{E}$ types among Indians of Southern Mexico and Guatemala.? Amer. F. hum. Genet., 12, 338.

, Neel, J. V., Livingston, F. B., Binson, G., Kunstadter, P., and Trombley, L. E. (1959). The frequencies of haptoglobin types in five populations. Ann. hum. Genet., 23, 175. 